\title{
Sweet Sorghum Planting Effects on Stalk Yield and Sugar Quality in Semi-Arid Tropical Environment
}

\author{
S. S. Rao,* J. V. Patil, P. V. V. Prasad,* D. C. S. Reddy, J. S. Mishra, A. V. Umakanth, \\ B. V. S. Reddy, and A. A. Kumar
}

\begin{abstract}
Sweet sorghum [Sorghum bicolor (L.) Moench] has potential as a bioenergy crop for producing food, fiber, and fermentable sugar. Unlike dryland grain sorghum, little information is available on the influence of staggered planting and genotypes, especially in semiarid tropical environments. The objectives of the present study were (i) to quantify the effects of planting time and genotype on stalk and biomass yields, juice sugar quality, and (ii) to identify the most productive genotypes and planting windows for sustainable feedstock supply. Four commercial sweet sorghum genotypes (SSV84, SSV74, CSV19SS, and CSH22SS) were planted on five planting dates (1 June, $16 \mathrm{June}, 1 \mathrm{July}, 16 \mathrm{July}$, and 1 August) during the rainy (June-October) season of 2008 and 2009 in Hyderabad $\left(17^{\circ} 27^{\prime} \mathrm{N}, 78^{\circ} 28^{\prime} \mathrm{E}\right)$, India. Planting in early and mid-June produced significantly $(P \leq 0.05)$ higher fresh stalk yield and grain yield than later planting dates. Commercial hybrid CSH22SS produced significantly more stalk, grain, sugar, and ethanol yield over genotypes SSV84 or SSV74. Based on the stalk yield, juice sugar quality, sugar, and ethanol yields, the optimum planting dates for sweet sorghum in semiarid tropical climate is early June to early July. Planting sweet sorghum during this time allows more feedstock to be harvested and hence extends the period for sugar mill operation by about 1 mo, that is, from the first to the last week of October.
\end{abstract}

$S^{n}$ WEET SORGHUM IS an important crop grown in a wide range of environments in Asia, Africa, and the Americas, well adapted for areas between $40^{\circ} \mathrm{N}$ and $40^{\circ} \mathrm{S}$ latitudes. Sweet sorghum accumulates fermentable sugars (10-20\%) in the stalk and thus has an advantage for producing grain for food and bioethanol from stalk juice without compromising food security (Reddy et al., 2005). Sweet sorghum crop could be a biofuel feedstock for ethanol production in India (Hunsigi et al., 2010; Ratnavathi et al., 2010) and around the world (Rooney et al., 2007; Erickson et al., 2011; Whitfield et al., 2012). Sweet sorghum requires relatively little N (Dercas et al., 1995) and water (Mastrorilli et al., 1995; Curt et al., 1995) and is relatively more tolerant to drought and salinity, among other environmental stresses, in semiarid climates (Almodares and Hadi, 2009; Vasilakoglou et al., 2011). In India, sweet sorghum is primarily grown in the rainy season (JuneOctober) and is planted during the first fortnight of June (SrinivasaRao et al., 2009). The monsoon in the tropical India starts during the early to mid-June and ceases by late September or early October. The sweet sorghum planting normally coincides with monsoon onset and harvesting with monsoon recession under

S.S. Rao, J.V. Patil, J.S. Mishra, D.C.S. Reddy, and A.V. Umakanth, Directorate of Sorghum Research, Rajendrangar, Hyderabad, Andhra Pradesh, India; B.V.S. Reddy, and A.A. Kumar, International Crops Research Institute for the Semi-Arid Tropics (ICRISAT), Patancheru, Andhra Pradesh, India; S.S. Rao, and P.V.V. Prasad, Dep. of Agronomy, Kansas State Univ., 2004 Throckmorton Plant Science Center, Manhattan, KS 66506. Received 26 Mar. 2013. ${ }^{*}$ Corresponding authors (ssrao@sorghum.res.in; vara@ksu.edu).

Published in Agron. J. 105:1458-1465 (2013)

doi:10.2134/agronj2013.0156

Copyright (c) 2013 by the American Society of Agronomy, 5585 Guilford Road, Madison, WI 53711. All rights reserved. No part of this periodical may be reproduced or transmitted in any form or by any means, electronic or mechanical, including photocopying, recording, or any information storage and retrieval system, without permission in writing from the publisher. dryland conditions. Normally, sweet sorghum is harvested during the first week of October ( 115-120 d after planting). Sugarcane, in contrast, is planted between December and February and harvested between late November and mid-April in the following year ( 12-14 mo from planting). Sugar mills in India operate from mid-November to early April ( $4.5 \mathrm{mo})$ and sit idle for rest of the year. The sweet sorghum feedstock can go to the sugar mills before sugarcane processing begins in mid-November. Thus, staggering sweet sorghum plantings with sugarcane can help supply feedstock for the $\sim 1.0$ mo period from the first to last week of October at the sugar mills in semiarid tropical Indian conditions $\left(15^{\circ}-24^{\circ} \mathrm{N}\right.$ latitude).

The biofuel industry requires the constant availability of biomass during most of the year, so a major constraint in that industry is lack of feedstock, especially from sweet sorghum, during a time best suited for biofuel processing industry (SrinivasaRao et al., 2009). Therefore, it is important to develop crop production practices that extend the feedstock availability as long as possible. Planting at different dates during the year is one option (Burks et al., 2013). In a study of monthly plantings of sweet sorghum in a temperate climate, May plantings produced high fermentable sugars, sugar, and ethanol yields (Teetor et al., 2011; Han et al., 2012). Similarly, Erickson et al. (2011) reported that early plantings (early April and May) produced higher sugar yields in both primary and ratoon-crop than late planting (June) in Florida. Strong interactions among genotypes, planting date, and timing of harvest were observed on both yield and composition of sweet sorghum juice (Tew and Cobill, 2006). Ferraris and CharlesEdwards (1986) reported that delayed planting decreased sugar concentrations at all stages of crop growth; cultivar Wray yielded $10.0 \mathrm{tha}^{-1}$ of sugar when planted early in the season but only

Abbreviations: $\mathrm{Tb}$, base temperature; $\mathrm{Tmax}$, maximum temperature; $\mathrm{Tmin}$, minimum temperature. 
$3.0 \mathrm{tha}^{-1}$ with late planting in southeast Queensland, Australia. Currently, the biofuel industry is promoting and commercializing sweet sorghum as one feedstock for bioethanol production in India and elsewhere (PrajIndustries Limited, 2012; TataChemicals Limited, 2012; AgriFuels Limited, 2012). However, they seek management options that can extend milling operations with minimum yield losses.

Staggered planting can help lengthen the time the feedstock can be used (Schaffert, 1992). However, much information on the impact of planting date on stalk and sugar yields are available on sweet sorghum genotypes grown in temperate climatic conditions (Han et al., 2012; Burks et al., 2013), but information is very limited on genotypes adapted to a semiarid tropical environment, particularly India. In addition, information on the effects of biweekly staggered planting on fresh stalk yield, sugar quality traits, sugar, and ethanol yields have not been adequately studied in semiarid tropical climates (SrinivasaRao et al., 2009). Information on genotype or germplasm is needed because tropical environments differ from temperate ones in both phenology and yield. Both photoperiod and temperature interact, thus further influencing yield especially for very late plantings. Furthermore, evaluating sweet sorghum across planting dates and identifying the best planting window in the rainy season (June-November) will not only benefit the sweet sorghum biofuel processing industry, but also allow farmers to plan planting and harvest operations for continuous feedstock supply (Rao et al., 2008).

Thus, the primary objectives of this research were to (i) evaluate commercially available sweet sorghum genotypes for their response to variable planting dates (weather); (ii) quantify the effects of planting date and genotype and their interaction on phenology, stalk, and biomass yields, juice sugar quality traits, sugar, and ethanol yields; and (iii) identify best genotype and planting and harvest window for extended feedstock supply.

\section{MATERIALS AND METHODS}

\section{Sweet Sorghum Genotypes and Experimental Design}

Four commercial sweet sorghum genotypes, three varieties (SSV84, SSV74, and CSV19SS) and one hybrid (CSH22SS), were evaluated in this study. Table 1 provides the pedigree details of genotypes. The experimental design was a split-plot with three replications, with planting dates assigned to main-plots, genotypes to sub-plots, and plots arranged in a randomized complete block design (RCBD). The plot size was $5.0 \mathrm{~m}$ by $3.6 \mathrm{~m}\left(18 \mathrm{~m}^{2}\right)$ each with 6 rows $5 \mathrm{~m}$ long.

\section{Experimental Site and Environmental Conditions}

The plots were planted on 1 June, 16 June, 1 July, 16 July, and 1 August during the rainy seasons of 2008 and 2009 at the experimental farm at the Directorate of Sorghum Research, Hyderabad, India $\left(17^{\circ} 27^{\prime} \mathrm{N}, 78^{\circ} 28^{\prime} \mathrm{E}\right.$, altitude: $524.6 \mathrm{~m}$ amsl). Soil at the experimental site was a clay loam (profile depth $\geq 1.0 \mathrm{~m}$; clay $50.1 \%$; silt $29.2 \%$; coarse sand $6.1 \%$; organic carbon $0.51 \%$; $\mathrm{pH} 7.5$; field capacity $36.5 \%$; wilting point $18.8 \%$; bulk density $1.28 \mathrm{~g} \mathrm{cc}^{-1}$; electrical conductivity $0.138 \mathrm{dS} \mathrm{m}^{-1}$; soil available $\mathrm{N}$ at $158.7 \mathrm{~kg} \mathrm{ha}^{-1}, \mathrm{P}$ at $15.8 \mathrm{~kg} \mathrm{ha}^{-1}$, and Kat $672 \mathrm{~kg} \mathrm{ha}^{-1}$ ). The environmental conditions during 2008 and 2009 cropping seasons are in Fig. 1. Accumulated thermal time was calculated from sowing to physiological maturity for each planting date. The accumulated thermal time $\left({ }^{\circ} \mathrm{Cd}\right)$ was computed by averaging weekly maximum (Tmax) and minimum (Tmin) temperatures and subtracting base temperature $\left(\mathrm{Tb}, 10^{\circ} \mathrm{C}\right)$.

\section{Crop Husbandry and Data Collection}

Two seeds were hand-planted at 5 -cm soil depth and thinned to 10 plants $\mathrm{m}^{-2}$ at 5 -leaf stage. A seeding rate of $10 \mathrm{~kg} \mathrm{ha}^{-1}$ and plant spacing of $60 \mathrm{~cm}$ between the rows and $15 \mathrm{~cm}$ within the row was followed in both the years. Herbicide atrazine (2-chloro-

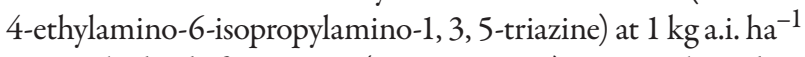
was applied $1 \mathrm{~d}$ after sowing (pre-emergence) to control weeds. Hand-weeding and intercultivation operations were done twice between 5-leaf and panicle initiation. The recommended dose of fertilizer was applied $\left(80-40-40 \mathrm{~kg} \mathrm{~N}-\mathrm{P}_{2} \mathrm{O}_{5}-\mathrm{K}_{2} \mathrm{O} \mathrm{ha}^{-1}\right.$ in the form of urea, single superphosphate, muriate of potash, respectively) with half the $\mathrm{N}$ and all $\mathrm{P}$ and $\mathrm{K}$ as basal; the rest of the $\mathrm{N}$ was side-dressed at panicle initiation. Recommended and need-based crop protection measures were taken to control pests and diseases. The crop planted on 1 June in both the years was sprinkler irrigated uniformly for germination and seedling establishment because very little rainfall occurred (Fig. 1). All subsequent plantings were raised under natural rainfall conditions

Table I. Pedigree details of sweet sorghum genotypes used in this research.

\begin{tabular}{|c|c|c|}
\hline Genotypes & Pedigree & Remarks \\
\hline SSV84 & $\begin{array}{l}\text { Selection from IS } 23568 \text { (PAB84)- } \\
\text { Zera-zera landrace, Ethiopia }\end{array}$ & $\begin{array}{l}\text { Time to flowering is } 84 \mathrm{~d} \text { and fresh stalk yield is } 35.6 \mathrm{Mg} \mathrm{ha}{ }^{-1} \text { based on } 52 \\
\text { multi-environment tests at the standard planting date in June second week. It is } \\
\text { the India's first sweet sorghum variety developed at Mahatma Phule Agricultural } \\
\text { University, Rahuri, India in 1992, and possessing high Juice }{ }^{\circ} \text { brix at physiological } \\
\text { maturity. }\end{array}$ \\
\hline SSV 74 & $\begin{array}{l}\text { Selection from } 23558 \text { (PAB74)-Zera-zera } \\
\text { landrace, Ethiopia }\end{array}$ & $\begin{array}{l}\text { Time to flowering is } 76 \mathrm{~d} \text { and fresh stalk yield is } 40.5 \mathrm{Mg} \mathrm{ha}^{-1} \text { based on } 52 \text { multi- } \\
\text { environment tests at the standard planting date in June second week. High brix, } \\
\text { inbred variety adapted to rainy season. It is the sweet sorghum-cum-forage variety } \\
\text { released by University of Agricultural Sciences, Dharwad, India. }\end{array}$ \\
\hline CSVI9SS & RSSV $2 \times$ SPV 462 & $\begin{array}{l}\text { Time to flowering is } 78 \mathrm{~d} \text { and fresh stalk yield is } 36.8 \mathrm{Mg} \mathrm{ha}^{-1} \text { based on } 52 \text { multi- } \\
\text { environment tests at the standard planting date in June second week. Inbred } \\
\text { variety developed at Mahatma Phule Agricultural University, Rahuri, India. Released } \\
\text { for cultivation in India in } 2005 \text { as inbred variety, and had tolerance to shoot fly. }\end{array}$ \\
\hline $\mathrm{CSH} 22 \mathrm{SS}$ & ICSA $38 \times$ SSV 84 & $\begin{array}{l}\text { Time to flowering is } 82 \mathrm{~d} \text { and fresh stalk yield is } 46.5 \mathrm{Mg} \mathrm{ha}{ }^{-1} \text { based on } 52 \text { multi- } \\
\text { environment tests at the standard planting date in June second week. This hybrid } \\
\text { was developed at Directorate of Sorghum Research, Rajendranagar, Hyderabad, } \\
\text { released for general cultivation in India during } 2005 \text {, and possessing tolerance to } \\
\text { shoot fly. }\end{array}$ \\
\hline
\end{tabular}


in both years. Approximately $50 \mathrm{~mm}$ irrigation water was applied to bring the soil near to field capacity.

\section{Phenology and Plant Height}

Days to 50\% flowering (anthesis) was measured on 10 tagged plants in each treatment plot as the time from date of seeding to the time that $50 \%$ of the plants in a plot extruded anthers in the mid-sections of the panicle (Vanderlip and Reeves, 1972). Days to physiological maturity was recorded when dark-spot (black-layer) appeared at the basal portion of seed (hilum) of the 10 tagged plants. At physiological maturity, plant height was recorded on the 10 tagged plants by measuring the height from the base of the plant to the tip of the panicle.

\section{Total Biomass, Stalk and Grain Yield}

At physiological maturity, 10 representative plants from the four central rows of each plot were sampled in all three replications for measuring fresh total biomass and stalk yield. After cutting the plants at ground level, total fresh biomass weight was recorded. The leaves along with sheath were then stripped and panicles with last internode (peduncle) were separated; the fresh weight of stripped stalk (hereafter referred as fresh stalk yield) was then recorded.
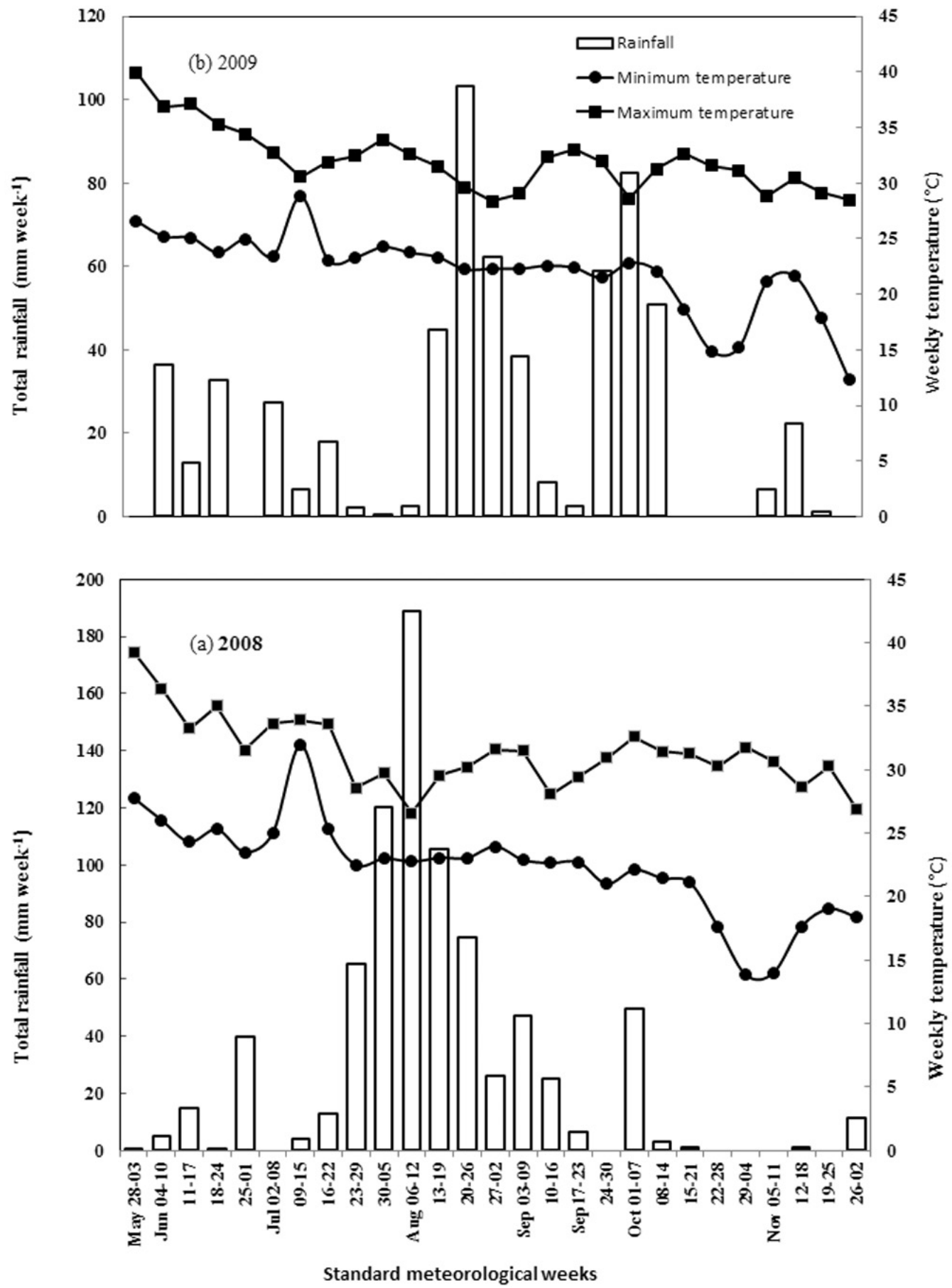

Fig. I. Weekly total rainfall $(\mathrm{mm})$, mean minimum (Tmin) and maximum (Tmax) temperatures $\left({ }^{\circ} \mathrm{C}\right)$ recorded at Agricultural Research Station, Rajendranagar $\left(17^{\circ} 27^{\prime} \mathrm{N}, 7^{\circ} 28^{\prime} \mathrm{E}\right.$, Altitude: $524.6 \mathrm{~m}$ amsl) weather station (approximately $200 \mathrm{~m}$ from the study site) from the last week in May to the last week in November (a) 2008 and (b) 2009. 
Grain yield was estimated from the 10 tagged plants (panicle). The panicles were dried, threshed, weighed, and grain yields $\left(\mathrm{kg} \mathrm{ha}^{-1}\right)$ computed; yields were adjusted to $14.5 \%$ moisture content.

\section{Juice Extraction and Juice Yield}

Stalk juice was extracted by passing the stalks through a power operated three-roller horizontal sugarcane machine miller soon after harvest. The stripped stalks were passed through the mill at least twice, and all extractable juice was removed from stalks, and weighed immediately. The extracted juice was filtered through Whatman filter paper immediately to remove large solids. Then $100 \mathrm{~mL}$ of the fresh juice was transferred to standard glass test tubes and processed immediately to estimate ${ }^{\circ}$ Brix. Soluble sugars were subsequently determined. Juice extraction rate (\%) was computed by dividing weight of fresh juice by weight of fresh stalks and multiplying by 100 . Juice yield $\left(\mathrm{Mg} \mathrm{ha}^{-1}\right)$ was computed by multiplying juice weight from 10 plants by plants per hectare.

\section{Juice Sugar Quality Traits}

Juice ${ }^{\circ}$ Brix (a measure of the mass ratio of total soluble solids to water) of the extracted juice was determined using a digital hand-held refractometer (Digital hand-held pocket refractometer PAL-1, Atago, Tokyo, Japan). This is referred as juice brix hereafter. Total soluble sugars were estimated by phenol sulfuric acid method using glucose as standard (Dubois et al., 1956). Reducing sugars in the fresh stalk juice were estimated by using the 3, 5 dinitrosalicylic acid (DNSA) reagent method (Miller, 1959). Reducing sugar content was calculated for glucose equivalents by comparing the absorbance with a standard curve of glucose. Sucrose content was directly measured using NIR Saccharimeter 880D (Optical Activity Limited, Cambridgeshire, UK) without using lead acetate clarification; this is hereafter referred to as juice sucrose content.
Total Sugar and Computed Ethanol Yield

Total sugar yield, which is a product of total soluble sugar percent in the juice, juice extraction ratio, and total juice weight, was estimated at physiological maturity according to Tsuchihashi and Goto (2004) and Murray et al. (2008). Ethanol yields were computed from total sugar yields using the procedure described by Smith and Buxton (1993).

\section{Statistical Analyses}

The data were analyzed using ANOVA following the procedure for split-plot design as outlined by Gomez and Gomez (1984). The results were analyzed separately by year and combined (both the years pooled). Results of both experiments (years) separately or combined showed similar responses and significance for all the traits. Therefore, the mean responses across the experiments (years) are presented. Least significant difference (LSD) values were calculated at 0.05 probability level wherever the $F$ test was significant. Data analysis was performed using WINDOSTAT statistical software (Windostat, 2011).

\section{RESULTS AND DISCUSSION}

\section{Environmental Conditions}

Rain was not uniformly distributed in 2008. With a total rainfall of $803 \mathrm{~mm}$ over the growing season, the crop received high rainfall during the mid-season (August), 18\% higher than the long-term average $(683 \mathrm{~mm}$ ) (Fig. 1). In 2009, total rainfall was $621 \mathrm{~mm}$, with one peak during pre-flowering (August) and one during hard-dough stage (early October) (Fig. 1). In both years, mid- to late October was dry during the grain-filling period for the crops planted on 16 July in 2008 and 1 August in 2009. Weekly mean Tmin and Tmax ranged from 13.9 to $27.8^{\circ} \mathrm{C}$ to 26.6 to $36.4^{\circ} \mathrm{C}$ in 2008 and 14.9 to $25.2^{\circ} \mathrm{C}$ to 28.4 to $36.9^{\circ} \mathrm{C}$ in 2009 during the crop growing period (Fig. 1). The accumulated thermal $\left({ }^{\circ} \mathrm{Cd}\right)$ time from planting to physiological maturity decreased from

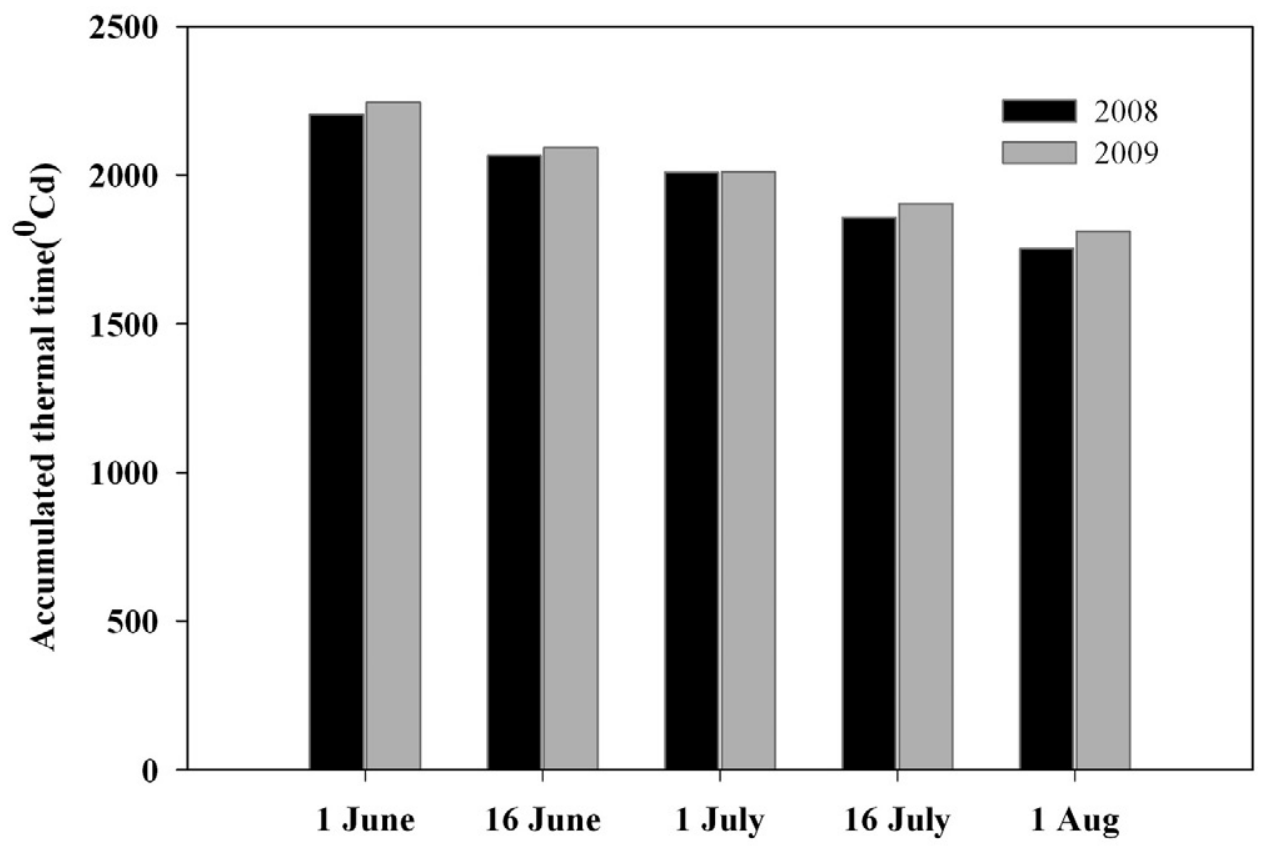

Planting dates

Fig. 2. Accumulated thermal time $\left({ }^{\circ} \mathrm{Cd}\right)$ calculated based on maximum (Tmax), minimum (Tmin), and base (Tb) temperatures during the crop growing periods of (solid bars) 2008 and (gray bars) 2009. 
1 June to 1 August planting in both years (Fig. 2). Accumulated thermal time decreased for 16 July and 1 August plantings over 1 June planting, falling from 15.7 to $20.4 \%$ in 2008 and from 15.2 to $19.3 \%$ in 2009 .

\section{Phenology and Plant Height}

Planting dates, genotypes, and their interaction on days to $50 \%$ flowering and physiological maturity all had significant effects. Across genotypes, the mean days to flowering was higher (86d) for the 1 June planting than subsequent plantings but the same for16 June and 1 July plantings (Table 2). On the other hand, crops planted on 16 July and 1 August went to $50 \%$ flowering in 11 and $12 \mathrm{~d}$ less than 1 June plantings (Table 2). Among genotypes, CSV19SS took significantly fewer days to flower (77 d). The trend in days to physiological maturity followed that of days to flowering. Days to flowering and maturity in later plantings (16 July and 1 August) were reduced because of the decline in photoperiod and accumulated thermal time from planting to physiological maturity (Fig. 2).
Significant decreases (34\%) in plant height were found in crops planted in August (Table 3). In general, a longer season increased plant height. Almodares and Darany (2006) also reported increased plant height in sweet sorghum with earlier planting dates. Among the sweet sorghum genotypes, CSH22SS was the tallest.

\section{Fresh Total Biomass and Fresh Stalk Yield}

Planting date also had significant effects (Table 3), as did genotype (Table 4), on total fresh biomass and fresh stalk yield, but not on the interactions of planting date and genotype. Early plantings (1 June and 16 June) had similar and significantly more biomass (80.5 and $70.6 \mathrm{tha}^{-1}$, respectively) than all later plantings (Table 3). Among genotypes, CSH22SS (with $59.6 \mathrm{Mg} \mathrm{ha}^{-1}$ ) and SSV74 (with $55.6 \mathrm{Mg} \mathrm{ha}^{-1}$ ) produced more fresh stalk yields than the other two genotypes.

Similarly, the earliest planting (1 June) gave highest fresh stalk yield of $58.1 \mathrm{Mg} \mathrm{ha}^{-1}$. The decrease in stalk yield across the planting dates ranged from 24 to $69 \%$ (Fig. 3). Planting on 1 July decreased stalk yield by $47 \%$, on 16 July by $63 \%$, and on 1 August

Table 2. Influence of planting dates, genotypes and their interaction on phenology and grain yield of sweet sorghum genotypes grown under rainfed conditions in semiarid environment at Hyderabad, India. Data are pooled means of 2 yr.

\begin{tabular}{|c|c|c|c|c|c|}
\hline \multirow[b]{2}{*}{ Planting dates } & \multicolumn{4}{|c|}{ Genotypes } & \multirow[b]{2}{*}{ Mean } \\
\hline & SSV84 & SSV74 & CSVI9SS & CSH22SS & \\
\hline \multicolumn{6}{|c|}{ Duration to $50 \%$ flowering, days } \\
\hline I June & 88 & 87 & 82 & 86 & 86 \\
\hline 16 June & 83 & 81 & 80 & 82 & 82 \\
\hline I July & 85 & 81 & 79 & 80 & 81 \\
\hline 16 July & 78 & 75 & 72 & 77 & 75 \\
\hline I August & 74 & 75 & 72 & 74 & 74 \\
\hline Mean & 82 & 80 & 77 & 80 & \\
\hline \multicolumn{6}{|l|}{$\operatorname{LSD}(P=0.05)$} \\
\hline \multicolumn{6}{|l|}{ Genotypes (G): 0.7} \\
\hline \multicolumn{6}{|l|}{ Planting dates (P): I.7 } \\
\hline \multicolumn{6}{|l|}{$\mathrm{G} \times \mathrm{P}$ interaction: Significant } \\
\hline \multicolumn{6}{|c|}{ Duration of physiological maturity, days } \\
\hline I June & 128 & 126 & 123 & 127 & 126 \\
\hline I 6 June & 123 & $|2|$ & 119 & 122 & 121 \\
\hline I July & 125 & 121 & 119 & 120 & 121 \\
\hline 16 July & 118 & 115 & 112 & 118 & 116 \\
\hline I August & 114 & 115 & III & 115 & 114 \\
\hline Mean & 122 & 120 & 117 & 120 & \\
\hline \multicolumn{6}{|l|}{$\operatorname{LSD}(P=0.05)$} \\
\hline \multicolumn{6}{|l|}{ Genotypes (G): 0.8} \\
\hline \multicolumn{6}{|l|}{ Planting dates $(P): 2.4$} \\
\hline \multicolumn{6}{|l|}{$G \times P$ interaction: Significant } \\
\hline \multicolumn{6}{|c|}{ Grain yield, $\mathrm{Mg}$ ha $^{-1}$} \\
\hline I June & 4.32 & 3.26 & 2.09 & 5.38 & 3.76 \\
\hline 16 June & I.II & 1.78 & 0.87 & 2.19 & 1.49 \\
\hline I July & 0.98 & 1.03 & 0.76 & $1.5 \mathrm{I}$ & 1.07 \\
\hline 16 July & 0.86 & 0.89 & 0.61 & 1.30 & 0.92 \\
\hline I August & 0.68 & 0.86 & 0.51 & 0.99 & 0.76 \\
\hline Mean & 1.59 & 1.57 & 0.97 & 2.27 & \\
\hline \multicolumn{6}{|l|}{$\operatorname{LSD}(P=0.05)$} \\
\hline \multicolumn{6}{|l|}{ Genotypes (G): 0.06} \\
\hline \multicolumn{6}{|l|}{ Planting Dates (P): 0.31} \\
\hline$G \times P$ interaction: Significant & & & & & \\
\hline
\end{tabular}


Table 3. Influence of planting dates on various traits of sweet sorghum genotypes grown under rainfed conditions in semiarid environment at Hyderabad, India. Data are pooled means of $\mathbf{2}$ yr, and averaged across genotypes.

\begin{tabular}{|c|c|c|c|c|c|c|}
\hline \multirow[b]{2}{*}{ Traits } & \multicolumn{5}{|c|}{ Planting dates } & \multirow{2}{*}{$\begin{array}{c}\text { LSD } \\
(P=0.05)\end{array}$} \\
\hline & I June & I 6 June & I July & 16 July & I August & \\
\hline Plant height, $\mathrm{cm}$ & 363 & 378 & 303 & 268 & 240 & 106 \\
\hline Fresh total biomass, $\mathrm{Mg} \mathrm{ha}^{-1}$ & 80.5 & 70.6 & 50.6 & 29.4 & 28.3 & 18.5 \\
\hline Fresh stalk yield, $\mathrm{Mg} \mathrm{ha}^{-1}$ & 58.1 & 44.0 & 30.7 & 21.5 & 18.0 & 16.7 \\
\hline Juice yield, $\mathrm{Mg} \mathrm{ha}^{-1}$ & 27.8 & 19.4 & 15.6 & 10.2 & 7.9 & 12.3 \\
\hline Juice extraction, $\%$ & 48.5 & 46.8 & 51.2 & 50.0 & 43.3 & nst \\
\hline Juice ${ }^{\circ}$ Brix, $\%$ & 14.9 & 16.5 & 16.2 & 15.3 & 15.0 & ns \\
\hline Total soluble sugars, $\%$ & 12.6 & 13.4 & 13.1 & 10.8 & $\mathrm{II} . \mathrm{I}$ & ns \\
\hline Reducing sugars, $\%$ & 1.47 & 1.50 & 1.58 & 2.05 & 1.68 & ns \\
\hline Sucrose content, \% & 10.9 & 11.8 & 11.2 & 8.5 & 9.3 & ns \\
\hline Sugar yield, $M g \mathrm{ha}^{-1}$ & 3.30 & 2.61 & 2.01 & 1.17 & 0.93 & 0.80 \\
\hline Ethanol yield, $\mathrm{L} \mathrm{ha}^{-\mathrm{I}}$ & 1758 & 1373 & 1070 & 624 & 495 & 423 \\
\hline
\end{tabular}

† ns, not significant.

Table 4. Influence of genotypes on various traits of sweet sorghum grown under rainfed conditions in semiarid environment at Hyderabad, India. Data are pooled means of 2 yr, and averaged across planting dates.

\begin{tabular}{|c|c|c|c|c|c|}
\hline \multirow[b]{2}{*}{ Traits } & \multicolumn{4}{|c|}{ Genotypes } & \multirow[b]{2}{*}{$\operatorname{LSD}(P=0.05)$} \\
\hline & SSV84 & SSV74 & CSVI9SS & CSH22SS & \\
\hline Plant height, $\mathrm{cm}$ & 288 & 312 & 309 & 332 & 21.2 \\
\hline Fresh total biomass, $\mathrm{Mg} \mathrm{ha} \mathrm{ha}^{-1}$ & 46.8 & 55.6 & 45.5 & 59.6 & 7.0 \\
\hline Fresh stalk yield, $\mathrm{Mg} \mathrm{ha-l}$ & 31.5 & 34.7 & 30.7 & 40.8 & 5.0 \\
\hline Juice yield, Mg ha-l & I5.I & 15.6 & 14.1 & 18.9 & 2.44 \\
\hline Juice extraction, $\%$ & 47.5 & 49.5 & 46.0 & 48.8 & nst \\
\hline Juice ${ }^{\circ}$ Brix, $\%$ & 15.9 & 16.0 & 14.3 & 16. I & 0.9 \\
\hline Total soluble sugars, \% & 12.7 & 12.8 & 10.7 & 12.7 & 1.0 \\
\hline Reducing sugars, \% & 1.94 & 1.85 & 1.32 & 1.50 & 0.38 \\
\hline Sucrose content, \% & 10.5 & 10.7 & 9.2 & 10.9 & 1.0 \\
\hline Sugar yield, $M g$ ha $^{-1}$ & 1.88 & 2.20 & 1.50 & 2.43 & 0.30 \\
\hline Ethanol yield, $L$ ha $^{-1}$ & 1004 & 1171 & 785 & 1296 & 161 \\
\hline
\end{tabular}

$\dagger \mathrm{ns}$, not significant.

by $69 \%$ over planting on 1 June (Table 3 ). The commercial hybrid, CSH 22 SS produced significantly $(P \leq 0.05)$ more $(18.0 \%)$ stalk yield over inbred SSV74. The stalk yield did not differ significantly among inbred genotypes SSV74, SSV84, and CSV19SS.

Earlier reports from temperate climates showed biomass and stalk yield of sweet sorghums decreased when planted late (June and July) rather than early (April and May) (Teetor et al., 2011; Han et al., 2012; Burks et al., 2013). Our results show that planting sweet sorghum in the first fortnight (1-16 June) was optimal for maximum stalk yield under semiarid tropical conditions, with marginal decreases when planted a little later, on 1 July. The onset of monsoon season in the semiarid tropical India is from the first to second week of June, and the monsoon ceases by late September or early October. Growing the sweet sorghum before early June is not possible because, unlike temperate climates, no rainfall occurs from March to May (data not presented in Fig.1). Maximum air temperature is also very high from March to May $\left(35.0-42.0^{\circ} \mathrm{C}\right)$. Planting in July decreases yield of sweet sorghum because daylength decreases during the growing period. The maximum daylength at Hyderabad is 13.5 h in June, decreasing to $\sim 10.5 \mathrm{~h}$ in December. Sorghum is a short day plant, with panicle initiation when daylength reaches $\leq 12.0$ in tropical climate (Miller et al., 1968). This suggests that planting sweet sorghum can be staggered from 1 June to 1 July, and thus feedstock can be made available for milling for 1 mo during October. Higher total biomass and stalk yield of sweet sorghum from early planting may be due to higher total accumulated thermal time
(Fig. 2) and higher ambient air and soil temperatures associated with longer daylength during pre-flowering stages. Additionally, the proposed planting window from I June to 1 July would make possible milling of sweet sorghum during October for the biofuel industry before sugarcane processing starts under semiarid tropical conditions (Hunsigi et al., 2010).

\section{Grain Yield}

Planting dates, genotypes, and their interactions significantly affected grain yield (Table 2). Across planting dates and genotypes, the mean grain yield ranged from 0.51 to $5.38 \mathrm{Mg} \mathrm{ha}^{-1}$. High grain yield of $3.76 \mathrm{Mg} \mathrm{ha}^{-1}$ was realized in 1 June planting followed by large decreases (60.0-80.0\%) in subsequent plantings. Interaction between plantings and genotypes revealed that $\mathrm{CSH} 22 \mathrm{SS}$ recorded its highest yield $\left(5.38 \mathrm{Mg} \mathrm{ha}^{-1}\right)$ in the 1 June planting and remained consistently high across planting dates. Limited to no information is available on how planting date affects grain yield performance of sweet sorghum grown in temperate climatic conditions, possibly because most sweet sorghum genotypes are photoperiod sensitive and late maturing, producing very little or no grain under the long-day conditions of temperate environments. Research in temperate climates emphasizes syrup and ethanol production from sweet sorghum more than grain production (Ferraris, 1981). However, in semiarid tropical climate of India, sweet sorghum is grown both for biofuel (ethanol from stalk juice) and food (roti, an unleavened bread from sorghum flour) (Reddy et al., 2005; SrinivasaRao et al., 2009). Hence, both 


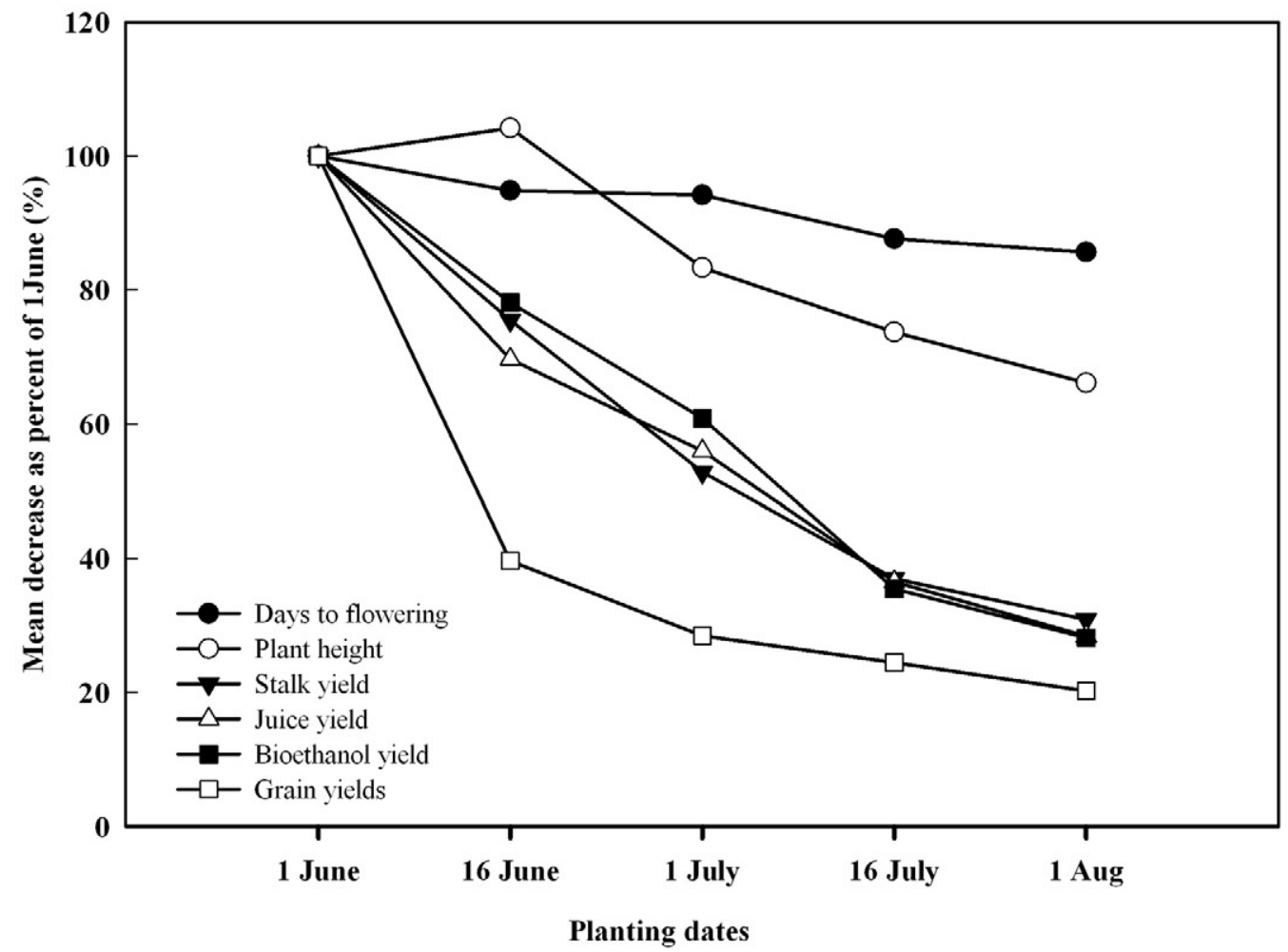

Fig. 3. Mean reduction (as percent of I June) for sweet sorghum phenology, stalk, juice, grain and ethanol yields, depicted as pooled mean data for 2008 and 2009.

high stalk yield and high grain yield require equal emphasis in developing sweet sorghum genotypes especially for the semiarid tropical conditions of India.

\section{Juice Extraction and Juice Yield}

Average percentage of juice extraction across the years did not differ significantly among planting dates and genotypes (Tables 3 and 4) or their interactions. Planting dates and genotypes showed significant effects on juice yields, but their interactions were not significant (Table 3). Juice yield was higher for the 1 June planting; the mean increase for 1 June planting was $43.2 \%$ over the 16 June planting and $78.2 \%$ over the 1 July planting. Juice yield decreased more from the 16 June planting date to the 1 August planting date, ranging from 30.0 to $72.0 \%$ (Fig. 3). Among genotypes, hybrid CSH22SS displayed 21.2\% more juice yields than SSV74.

The decrease in juice yield associated with delayed plantings was mainly due to shorter day-length and less availability of accumulated thermal time (Fig. 2) during the crop growing period. Teetor et al. (2011) also observed significant decreases in juice yields under staggered monthly plantings in temperate Arizona conditions.

\section{Juice Sugar Quality Traits}

The juice sugar quality was estimated in terms of juice ${ }^{\circ} \mathrm{Brix}$, total soluble sugars (TSS), reducing sugars (RS), and sucrose content, which showed only genotypes had any significant effect while planting dates (Tables 3 and 4) and their interactions did not. Among the genotypes, juice ${ }^{\circ} \mathrm{Brix}$, TSS, and sucrose content was similar in SSV84, SSV74, and CSH22SS (15.9, 16.0, and $16.1 \%$, respectively), while CSV19SS showed relatively lower quality traits.

\section{Total Sugar and Computed Ethanol Yields}

Planting dates and genotypes significantly affected sugar and computed ethanol yields (Tables 3 and 4), while the interaction effects were nonsignificant. Mean sugar yields ranged from 0.56 to $4.14 \mathrm{Mg} \mathrm{ha}^{-1}$, and ethanol yields ranged from 302 to $2202 \mathrm{~L} \mathrm{ha}^{-1}$ across planting dates and genotypes Sugar yields increased by $26.4 \%$, and ethanol by $28.0 \%$ from the 1 June planting to the 16 June planting, but the treatments were not statistically different. Both sugar and ethanol yields decreased by $23.0 \%$ from the 16 June planting to the 1 July planting, but again neither were statistically different (Table 3). The mean decrease (39.0\%) from the 1 June planting to the 1 July planting in both sugar and ethanol yield was significant (Fig. 3). Furthermore, both sugar and ethanol yields decreased markedly from the 1 June planting to the 16 July planting $(65.0 \%)$ and from the 1 June planting to the 1 August planting (72.0\%). Commercial hybrid CSH22SS produced $29.0 \%$ more ethanol than SSV84 and 63.0\% more ethanol than CSV19SS, a significant increase (Table 4). Among the varieties, SSV74 yielded $16.6 \%$ more ethanol than SSV84 and 49.2\% more than CSV19SS. Our results on sugar and ethanol yields revealed that although sugar and ethanol yields decreased from 1 June to 1 July, planting sweet sorghum from 1 June to 1 July remains feasible in semiarid tropical rainy season climates. This should extend the milling period for biofuel processing facilities by about 1 mo from the first to last week of October; continuous supply of feedstock is necessary to sustain the viability of sweet sorghum ethanol value chain.

Sweet sorghum produced higher sugar and ethanol yields in early plantings (April-May) in temperate (Teetor et al., 2011; Han et al., 2012) and Mediterranean climates in Egypt (Abd El-Razek and Besheit, 2009). Burks et al. (2013) suggested that at College 
Station, TX, planting both early maturing hybrids and using later planting dates would extend the harvest season of sweet sorghum, which is complementary to sugarcane harvest. Early plantings (1 June) showed higher sugar yields through increased stalk yield, juice extraction, and juice yield, but the sugar concentration (Juice ${ }^{\circ} \mathrm{Brix}$ ) did not improve to parallel stalk and juice yields (Table 3). Thus, future genetic improvement of sweet sorghum for sugar and ethanol yields should aim to combine both high juice sugar concentration and stalk yield apart from greater grain yields. This can be achieved by agronomic practices that consider more adaptive cultivars and optimal planting dates.

\section{CONCLUSIONS}

This research suggests that the planting window for sweet sorghum can extend from the first week of June to the first week of July in the semiarid tropical rainy season climatic conditions of India. This will help facilitate continuous feedstock supply for another month, that is, from first to last week of October, at sweet sorghum biofuel processing facilities. Commercial hybrid CSH22SS provided the highest yield followed by variety SSV74 for staggering of planting under dryland conditions. The additional milling operation time before sugarcane processing begins in mid-November is very useful especially in semiarid tropical India, where sugarcane and sweet sorghum can be grown in the similar agro-climatic conditions. Furthermore, the advantage of sweet sorghum is that it can be grown in dryland conditions without any supplemental irrigation during the monsoon, unlike sugarcane where more irrigation is required.

\section{ACKNOWLEDGMENTS}

Financial assistance received from National Agricultural Innovation Project, Indian Council of Agricultural Research, New Delhi, India under the sub-project namely "value chain model for bio-ethanol production from sweet sorghum in rainfed areas through collective action and partnership" is gratefully acknowledged for conduct of this experiment financial support.

\section{REFERENCES}

Abd El-Razek, A.M., and S.Y. Besheit. 2009. Potential of some sweet sorghum (Sor ghum bicolor L. Moench) varieties for syrup and ethanol production in Egypt. Sugar Tech. 11:239-245. doi:10.1007/s12355-009-0041-5

AgriFuels Limited. 2012. List of known sweet sorghum renewable energy projects. AgriFuels Ltd., Connecticut Center for Advanced Technol. (CCAT), East Hartford, CT. www.agrifuels.com.au/OtherSweetSorghumBiofuelProjects.htm (accessed 2 Mar. 2013).

Almodares, A., and S.M. Darany. 2006. Effects of planting date and time of nitrogen application on yield and sugar content of sweet sorghum. J. Environ. Biol. 27:601-605.

Almodares, A., and M.R. Hadi. 2009. Production of bioethanol from sweet sorghum: A review. African J. Agric. Res. 4:772-780.

Burks, P.S., T.J. Felderhoff, P. Howard, H.P. Viator, and W.L. Rooney. 2013. The influence of hybrid maturity and planting date on sweet sorghum productivity during the harvest season. Agron. J. 105:263-267. doi:10.2134/agronj2012.0317

Curt, M.D., J. Fernandez, and M. Martinez. 1995. Productivity and water use efficiency of sweet sorghum (Sorghum bicolor (L.) Moench) cv. Keller in relation to water regime. Biomass Bioenergy 8:401-409. doi:10.1016/0961-9534(95)00036-4

Dercas, N., C. Panoutsou, C. Dalianis, and C. Sooter. 1995. Sweet sorghum (Sorghum bicolor [L.] Moench) response to four irrigation and two nitrogen fertilization rates. In: M. Chartier et al., editors, Proceedings of the Eighth E.C Conference on Biomass for Energy, Environment, Agriculture, Vol. 1. Pergamon Press, UK. p. 629-639.

Dubois, M., K.A. Gilles, J.K. Hamilton, P.A. Rebers, and F. Smith. 1956. Colorimetric method for determination of sugars and related substances. Anal. Chem. 28:350356. doi:10.1021/ac60111a017
Erickson, J.E., Z.R. Helsel, K.R. Woodard, J.M.B. Vendramini, Y. Wang, L.E. Sollenberger, and R.A. Gilbert. 2011. Planting date affects biomass and brix of sweet sorghum grown for biofuel across Florida. Agron. J. 103:1827-1833. doi:10.2134/ agronj2011.0176

Ferraris, R. 1981. Early assessment of sweet sorghum as an agro industrial crop 1.Varietal evaluation. Aust.J. Exp. Agric. Anim. Husb. 21:75-82. doi:10.1071/EA9810075

Ferraris, R., and D.A. Charles-Edwards. 1986. A comparative analysis of the growth of sweet and forage sorghum crops. II. Accumulation of soluble carbohydrates and nitrogen. Aust. J. Agric. Res. 37:513-522. doi:10.1071/AR9860513

Gomez, K.A., and A.A. Gomez. 1984. Statistical procedures for agricultural research. 2nd ed. John Wiley \& Sons, New York.

Han, K.-J., H.W. Alison, W.D. Pitman, D.F. Day, M. Kim, and L. Madsen. 2012. Planting date and harvest maturity impact on biofuel feedstock productivity and quality of sweet sorghum grown under temperate Louisiana conditions. Agron. J. 104:1618-1624. doi:10.2134/agronj2012.0213

Hunsigi, G., N.R.Yekkeli, and B.Y. Kongawad. 2010. Sweet stalk sorghum: An alternative sugar crop for ethanol production. Sugar Tech. 12:79-80. doi:10.1007/ s12355-010-0017-5

Mastrorilli, M., N. Katerji, G. Rana, and P. Steduto. 1995. Sweet sorghum in Mediterranean climate: Radiation use and biomass water use efficiencies. Ind. Crops Prod. 3:253-260. doi:10.1016/0926-6690(94)00002-G

Miller, F.R., D.K. Barnes, and H.J. Cruzado. 1968. Effect of tropical photoperiods on the growth of sorghum when grown in 12 monthly plantings. Crop Sci. 8:499502. doi:10.2135/cropsci1968.0011183X000800040032x

Miller, G. 1959. Use of dinitrosalicylic acid reagent for determination of reducing sugar. Anal. Chem. 31:426-428. doi:10.1021/ac60147a030

Murray, S.C., A. Sharma, W.L. Rooney, P.E. Klein, J.E. Mullet, S.E. Mitchell, and S. Kresovich. 2008. Genetic improvement of sorghum as a biofuel feedstock: I. QTL for stem sugar and grain nonstructural carbohydrates. Crop Sci. 48:2165-2179. doi:10.2135/cropsci2008.01.0016

PrajIndustries Limited. 2012. Sweet sorghum to ethanol. Technology, plant and machinery, Praj House, Bavdhan, Pune, India. www.praj.net/media/sweetsorghum.pdf (accessed 2 Mar. 2013).

Rao, S.S., N. Seetharama. B. DayakarRao, C.V. Ratnavathi, and Ch. S. Reddy. 2008. Sweet sorghum-A potential energy crop for biofuel production in India. In: B.V.S. Reddy, S. Ramesh, A. Ashok Kumar, and C.L.L. Gowda, editors, Sorghum improvement in the new millennium. Int. Crops Res. Inst. for the Semi-Arid Tropics, Andhra Pradesh, India. p. 281-288,340.

Ratnavathi, C.V., K. Suresh, B.S.V. Kumar, M. Pallavi, V.V. Komala, and N. Seetharama. 2010. Study on genotypic variation for ethanol production from sweet sorghum juice. Biomass Bioenergy 34:947-952. doi:10.1016/j.biombioe.2010.02.002

Reddy, B.V.S., S. Ramesh, P.S. Reddy, B. Ramaiah, P.M. Salimath, and R. Kachapur. 2005. Sweet sorghum-A potential alternative raw material for bio-ethanol and bio-energy. Inter. Sorghum Millet Newslet. 46:79-86.

Rooney, W.L., J. Blumenthal, B. Bean, and J.E. Mullet. 2007. Designing sorghum as a dedicated bioenergy feedstock. Biofuels Bioprod. Biorefin. 1:147-157. doi:10.1002/bbb. 15

Schaffert, R.E. 1992. Sweet sorghum substrate for industrial alcohol. In: M.I. Gomez, L.R. House, L.W. Rooney, and D.A.V. Dendy, editors, Utilization of sorghum and millets. Int. Crops Res. Inst. for the Semi-Arid Tropics, Patancheru, India. p. 131-137.

Smith, G.A., and D.R. Buxton. 1993. Temperate zone sweet sorghum ethanol production potential. Bioresour. Technol. 43:71-75. doi:10.1016/0960-8524(93)90086-Q

SrinivasaRao, P., S.S. Rao, N. Seetharama, A.V.Umakanth, P.S. Reddy, B.V.S.Reddy, and C.L.L. Gowda. 2009. Sweet sorghum as a biofuel feedstock and strategies for its improvement. Information Bull. 77. Int. Res. Inst. for the Semi-Arid Tropics, Andhra Pradesh, India.

TataChemicals Limited. 2012. Biofuels. TataChemcials, Fort, Mumbai. www. tatachemicals.com/products/biofuels.htm (accessed 2 Mar. 2013).

Teetor, V.H., D.V. Duclos, E. Wittenberg, K.M. Young, J. Chawhuaymak, M.R. Riley, and D.T. Ray. 2011. Effects of planting date on sugar and ethanol yield of sweet sorghum grown in Arizona. Ind. Crops Prod. 34:1293-1300. doi:10.1016/j. indcrop. 2010.09 .010

Tew, T.L., and R. Cobill. 2006. Evaluation of sweet sorghum as a complementary bioenergy crop to sugarcane in Louisiana. J. Amer. Soc. Sugar Cane Tech. 26:57-58.

Tsuchihashi, N., and Y. Goto. 2004. Cultivation of sweet sorghum and determination of its harvest time to make use as the raw material for fermentation practical during rainy season in dryland of Indonesia. Plant Prod. Sci. 7:442-448. doi:10.1626/ pps.7.442

Vanderlip, R.L., and H.E. Reeves. 1972. [Sorghum bicolor (L.) Moench.] Growth stages of sorghum. Agron. J. 64:13-16. doi:10.2134/agronj1972.0002196200640001 $0005 \mathrm{x}$

Vasilakoglou, I., K. Dhima, N. Karagiannidis, and T. Gatsis. 2011. Sweet sorghum productivity for biofuels under increased soil salinity and reduced irrigation. Field Crops Res. 120:38-46. doi:10.1016/j.fcr.2010.08.011

Whitfield, M.B., M.S. Chinn, and M.W. Veal. 2012. Processing of materials derived from sweet sorghum for biobased products. Ind. Crops Prod. 37:362-375. doi:10.1016/j.indcrop.2011.12.011

Windostat. 2011. Windostat Services, Hyderabad, Andhra Pradesh, India. www.windostat.org (accessed 1 Jan. 2013). 